\title{
ANALISIS KELAYAKAN FINANSIAL USAHATANI ALPUKAT DI KECAMATAN SEMBALUN KABUPATEN LOMBOK TIMUR
}

\section{FINANCIAL FEASIBILITY ANALYSIS OF AVOCADO FARMING IN SEMBALUN DISTRICT EAST LOMBOK REGENCY}

\author{
M Zuhral Anwari ${ }^{1 *}$, Sri Maryati ${ }^{2}$, I Ketut Budastra ${ }^{3}$ \\ ${ }^{1,2,3}$ Program Studi Agribisnis, Universitas Mataram, Kota Mataram, Indonesia \\ *Email Penulis Korespondensi: zuhralanwari017@ gmail.com
}

\begin{abstract}
Abstrak
Alpukat adalah salah satu tanaman hortikultura yang banyak dikembangkan di Indonesia khususnya di Provinsi NTB. Provinsi NTB tercatat memiliki jumlah pohon sebanyak 42.581 pohon dengan produksi $44.665 \mathrm{kw}$ pada Tahun 2017, sedangkan Kabupaten Lombok Timur Tahun 2017 merupakan penghasil buah alpukat utama di NTB dengan kepemilikan pohon sebanyak 31.468 pohon dengan produksi 31.215. Kecamatan Sembalun termasuk sebagai wilayah pengembangan usahatani alpukat di Kabupaten Lombok Timur. Tercatat produksi alpukat di Kecamatan Sembalun pada tahun 2017 sebesar 26.173 kw. Tujuan penelitian ini untuk menganalisa kelayakan finansial dari investasi usahatani alpukat di Kecamatan Sembalun Kabupaten Lombok Timur. Metode penelitian bersifat deskriptif. Unit analisis adalah petani yang membudidayakan tanaman alpukat di Kecamatan Sembalun. Kecamatan Sembalun ditentukan sebagai daerah penelitian secara purposive sampling. Penentuan jumlah sampel menggunakan teknik Slovin yakni 40 petani responden sedangkan penetapannya menggunakan teknik accidental sampling. Jenis data yang digunakan yaitu data kuantitatif dan data kualitatif. Sumber data adalah data primer dan data skunder. Variabel yang diukur adalah umur ekonomis tanaman, input dan output usahatani. Pengumpulan data dilakukan dengan teknik survei. Analisis data menggunakan Net Present Value, Internal Rate Return, Payback Period dan analisis sensitivitas. Hasil penelitian menunjukkan NPV Rp 434.846.907/ha/15 tahun (NPV > 0), IRR sebesar 54,24\% (IRR > dari tingkat suku bunga yang berlaku), Payback Period sebesar 4,3 (investasi awal akan dikembalikan dalam jangka waktu 4,3 tahun) dan sensitivitas $<1$ sehingga usahatani alpukat ini tetap layak diusahakan dan tidak peka atau sensitive terhadap perubahan yang terjadi.
\end{abstract}

Kata Kunci : Analisis, Finansial, dan Alpukat

\begin{abstract}
Avocado is a horticultural crop that is widely developed in Indonesia, especially in the Province of NTB. NTB Province is recorded as having 42,581 trees with a production of 44,665 kw in 2017, while East Lombok Regency in 2017 is the main avocado producer in NTB with tree ownership of 31,468 trees with a production of 31,215. Sembalun Subdistrict is included as an avocado farming development area in East Lombok Regency. Avocado production in Sembalun District in 2017 was recorded at 26,173 kw. The purpose of this study was to analyze the financial feasibility of investing in avocado farming in Sembalun District, East Lombok Regency. The research method is descriptive. The unit of analysis is the farmers who cultivate avocado plants in Sembalun District. Sembalun sub-district was determined as the research area by purposive sampling. Determination of the number of samples using the Slovin technique, namely 40 respondent farmers, while the determination using accidental sampling technique. The types of data used are quantitative data and qualitative data. The data sources are primary data and secondary data. The variables measured were the economic age of the plant, farm input and output. Data collection was carried out by survey techniques. Data analysis using Net Present Value, Internal Rate Return, Payback Period and sensitivity analysis. The results showed an NPV of IDR 434,846,907 / ha / 15 years (NPV>0), an IRR of $54.24 \%$ (IRR> of the prevailing interest rate), a Payback Period of 4.3 (the initial investment will be returned within a period of time. 4,3 years) and sensitivity $<1$ so that this avocado farming is still feasible to be cultivated and is not sensitive or sensitive to the changes that occur.
\end{abstract}

Keywords: Analysis, Finance, and Avocado

Anwari, M.Z, Maryati, S., dan Budastra, I.K. 


\section{PENDAHULUAN}

Salah satu tanaman hortikultura yang banyak dikembangkan di Indonesia khususnya di Provinsi NTB yaitu alpukat. Produksi alpukat di Indonesia tahun 2013 hingga 2017 dikatakan fluktuatif namun cenderung mengalami peningkatan. Berdasarkan data Badan Pusat Statistik dan Direktorat Jenderal Hortikultura (2018), produksi buah alpukat tahun 2017 dengan luas panen 23.121 ha sebesar 363.148 ton, dengan tingkat pertumbuhan produksi dari Tahun 2016 ke 2017 sebesar 19,09\% (Badan Pusat Statistik dan Direktorat Jenderal Hortikultura 2018).

Provinsi NTB tercatat memiliki jumlah pohon alpukat sebanyak 42.581 pohon dengan hasil produksi $44.665 \mathrm{kw}$ pada tahun 2017, sedangkan Kabupaten Lombok Timur tahun 2017 merupakan penghasil buah alpukat utama di NTB dengan kepemilikan pohon sebanyak 31.468 pohon dengan produksi $31.215 \mathrm{kw}$ atau sebesar $69.89 \%$ dari total produksi buah alpukat Provinsi Nusa Tenggara Barat (Statistik Produksi Tanaman Hortikultura Provinsi NTB 2017). Kabupaten Lombok Timur terdiri dari dua puluh kecamatan, diantara dua puluh kecamatan tersebut terdapat beberapa kecamatan yang melakukan kegiatan usahatani alpukat. Kecamatan Sembalun merupakan salah satu dari dua puluh kecamatan yang ada di Kabupaten Lombok Timur yang termasuk sebagai wilayah pengembangan usahatani alpukat. Tercatat jumlah produksi alpukat di Kecamatan Sembalun pada tahun 2017 sebesar $26.173 \mathrm{kw}$ atau $83,85 \%$ dari total produksi alpukat di Kabupaten Lombok Timur (Dinas Pertanian Kabupaten Lombok Timur, 2019).

Peningkatan luas panen alpukat di Kecamatan Sembalun disebabkan oleh adanya beberapa petani yang melakukan penggantian usahatani dari komoditas sebelumnya menjadi komoditas alpukat. Selain pola tanam monokultur, mayoritas petani alpukat di Kecamatan Sembalun juga mengusahakan alpukat dengan pola tanam tumpangsari atau campuran. Jenis tanaman tumpangsari pada usahatani alpukat adalah tanaman kopi, cengkeh dan vanili.

Idealnya pohon alpukat berbuah diusia 3 tahun dari bibit perbanyakan secara vegetative (okulasi, sambung, tempel). Namun apabila ditanam di dataran tinggi, pohon alpukat mampu berbuah lebih cepat sekitar usia 2 tahun sedangkan ketika ditanam di dataran rendah rata-rata pohon alpukat berbuah yaitu pada usia 4 tahun. Hal ini juga tidak terlepas dari cara perawatan pohon alpukat tersebut. Produktivitas alpukat tentu berbeda-beda tergantung dari jenis alpukatnya. Pohon alpukat akan menghasilkan buah sekitar $30 \mathrm{~kg}-75 \mathrm{~kg}$ setiap pohonnya diusia 3 tahun dan setiap tahunnya akan bertambah sekitar 30\% - 50\% dari hasil sebelumnya. Tingkat produktivitas pohon alpukat yaitu sampai 10 tahun sehingga persentase pertambahan akan menurun menjadi $20 \%$ setelah usia 10 tahun dan rata-rata setelah usia 15-20 tahun, produktivitas buah akan stabil. Selain itu agar pohon mampu tumbuh besar dengan baik, maka diusia pohon 11 - 12 tahun mulai ada penebangan atau peremajaan dengan mengurangi 1/4 dari populasi pohon.

Usahatani alpukat membutuhkan modal yang tinggi, biaya investasi yang besar dan masa pengembalian yang cukup lama serta kemungkinan bervariasi antar wilayah. Oleh karena itu diperlukan analisis kelayakan finansial dan sensitivitas untuk mengetahui apakah usahatani alpukat layak untuk diusahakan oleh petani di Kecamatan Sembalun. Kelayakan finansial usahatani alpukat dapat dijadikan dasar dalam pengambilan keputusan bagi petani dalam memilih usahatani yang akan dilakukannya. Karena alpukat adalah tanaman tahunan, maka kelayakan finansial usahatani alpukat dalam penelitian ini dinilai berdasarkan kriteria kelayakan investasi. Berdasarkan dari data-

Anwari, M.Z, Maryati, S., dan Budastra, I.K. 
data dan uraian yang sudah dikemukakan sebelumnya, maka dipandang perlu untuk melakukan penelitian mengenai Analisis Kelayakan Finansial Usahatani Alpukat di Kecamatan Sembalun Kabupaten Lombok Timur. Berdasarkan uraian tersebut, maka tujuan dari penelitian ini yaitu menganalisa kelayakan financial dari investasi usahatani alpukat di Kecamatan Sembalun Kabupaten Lombok Timur.

\section{METODOLOGI PENELITIAN}

\section{Metode Penelitian}

Metode penelitian ini bersifat deskriptif yaitu memecahkan suatu permasalahan yang terjadi pada waktu sekarang dengan cara mengumpulkan data, menyusun, menganalisa, dan menarik kesimpulan serta menginterpretasikan (Ridwan, 2007).

\section{Unit Analisis}

Unit analisis dalam penelitian ini adalah petani yang melakukan budidaya tanaman alpukat di Kecamatan Sembalun.

\section{Penentuan Sampel}

\section{Penentuan daerah penelitian}

Penentuan daerah penelitian dilakukan secara purposive sampling atau secara sengaja berdasarkan pertimbangan tertentu yang telah dibuat terhadap suatu objek yang sesuai dengan tujuan. Desa yang dipilih di Kecamatan Sembalun yaitu Desa Sembalun, Sembalun Lawang dan Sajang karena merupakan sentra usahatani alpukat terbesar di Kecamatan Sembalun.

\section{Penentuan responden}

Jumlah Populasi dalam penelitian ini adalah seluruh petani alpukat yang ada di Kecamatan Sembalun Kabupaten Lombok Timur yang berjumlah 302 petani. Penentuan jumlah sampel dilakukan dengan menggunakan teknik Slovin (Sugiyono, 2009) dengan formula sebagai berikut:

$$
n=\frac{N}{1+N(e)^{2}}
$$

Keterangan:

$\mathrm{n}=$ Ukuran sampel/jumlah responden

$\mathrm{N}=$ Ukuran populasi

$\mathrm{E}=$ Presentase kelonggaran ketelitian kesalahan pengambilan sampel yang masih bisa ditolerir; e $=0,15$. Jadi rentang sampel yang dapat diambil dari teknik Slovin adalah antara 10-20\% dari populasi penelitian.

Berdasarkan formula di atas, diperoleh jumlah sampel sebagai berikut:

$$
n=\frac{302}{1+302(0,15)^{2}}=\frac{302}{7,79}=38,77
$$

Berdasarkan perhitungan tersebut sampel yang mejadi responden dalam penelitian ini disesuaikan menjadi sebanyak 40 orang petani alpukat di Kecamatan Sembalun.Hal ini dilakukan untuk mempermudah dalam pengolahan data dan hasil pengujian yang lebih baik. Penentuan responden menggunakan accidental sampling, yaitu penentuan sampel berdasarkan kebetulan. Petani yang kebetulan bertemu dengan peneliti dapat digunakan sebagai sampel apabila dipandang orang yang kebetulan ditemui itu cocok sebagai sumber data (Sugiyono, 2009). 


\section{Jenis dan Sumber data}

\section{Jenis Data}

Jenis data terdiri dari dua yaitu data kuantitatif dan data kualitatif. Sedangkan sumber data pada penelitian ini adalah data primer dan data skunder.

\section{Variabel dan Cara Pengukuran}

Variabel adalah obyek penelitian atau yang menjadi titik perhatian suatu penelitian (Arikunto dan Suharsimi, 2006). Variabel dalam penelitian ini adalah:

a. Umur ekonomis adalah jumlah tahun proyek berjalan sampai proyek tidak menghasilkan keuntungan yaitu selama 15 tahun. Periode analisa disesuaikan dengan informasi dari responden tentang usia ekonomis tanaman alpukat.

b. Input (biaya) usahatani adalah seluruh korbanan yang dipergunakan dalam kegiatan usahatani selama umur proyek. Biaya usahatani terdiri dari biaya investasi dan biaya operasional.

c. Output (manfaat) usahatani adalah nilai produksi total dalam suatu kegiatan usahatani. Produksi adalah jumlah output (hasil panen) alpukat dari luas lahan petani pertahun selama umur proyek diukur dalam satuan $(\mathrm{Kg} / \mathrm{Ha})$.

\section{Cara Pengumpulan Data}

Pengumpulan data dilakukan dengan menggunakan teknik survey yaitu dengan wawancara langsung dengan responden yakni petani alpukat yang berpedoman pada daftar pertanyaan yang telah dipersiapkan sebelumnya.

\section{Analisis Data}

\section{Net Present Value (NPV)}

Net Present Value merupakan selisih nilai sekarang penerimaan dengan nilai sekarang dari pengeluaran pada tingkat suku bunga tertentu. Secara matematis:

$$
N P V=\sum_{t=0}^{n} \frac{\mathrm{Bt}-\mathrm{Ct}}{(1+\mathrm{i})^{\mathrm{t}}}
$$

Dimana:

$\mathrm{Bt}=$ manfaat yang diperoleh pada tahun ke- $\mathrm{t}$

$\mathrm{Ct}=$ biaya yang dikeluarkan pada tahun ke- $\mathrm{t}$

$\mathrm{i}=$ tingkat suku bunga/discount rate $(\%)$

$\mathrm{n}=$ umur ekonomis proyek

Kriteria kelayakan investasi metode NPV adalah suatu investasi dinyatakan layak jika NPV > 0 atau bernilai positif. Sebaliknya, jika NPV $<0$ atau bernilai negative maka investasi dinyatakan tidak layak.

\section{Internal Rate Return (IRR)}

IRR adalah tingkat suku bunga (discount rate) yang membuat besarnya net present value (NPV) usaha sama dengan nol. Secara matematis nilai tersebut dirumuskan sebagai berikut:

Dimana:

$$
\mathrm{IRR}=\mathrm{i}_{1}+\frac{\mathrm{NPV}_{1}}{\mathrm{NPV}_{1}-\mathrm{NPV}_{2}} \mathrm{x}\left(\mathrm{i}_{2}-\mathrm{i}_{1}\right)
$$

$\mathrm{NPV}_{1}=\mathrm{NPV}$ yang bernilai positif

$\mathrm{NPV}_{2}=\mathrm{NPV}$ yang bernilai negative

$\mathrm{i}_{1}=$ discount rate yang menghasilkan NPV positif

Anwari, M.Z, Maryati, S., dan Budastra, I.K. 
$\mathrm{i}_{2}=$ discount rate yang menghasilkan NPV negative

Suatu usaha atau kegiatan investasi dikatakan layak apabila nilai IRR lebih besar dari tingkat discount rate yang telah ditentukan. Sebaliknya jika nilai IRR lebih kecil dari tingkat discount rate, maka usaha atau kegiatan investasi tidak layak untuk dijalankan.

\section{Payback Period (PP)}

Payback Period merupakan penilain investasi suatu proyek yang didasarkan pada pelunasan biaya investasi berdasarkan manfaat bersih dari suatu proyek. Kriteria kelayakannya: jika masa pengembalian lebih pendek dari umur ekonomis usaha maka proyek layak dikembangkan, sedangkan jika masa pengembalian lebih lama dari umur ekonomis usaha maka proyek tidak layak dikembangkan (Kusuma dan Mayasti, 2014). Secara Matematis dirumuskan sebagai berikut:

$$
\mathrm{PP}=\frac{\text { Nilai Investasi }}{\text { Kas Masuk Bersih }}
$$

\section{Analisis Sensitivitas}

Analisis sensitivitas perlu untuk dilakukan karena setiap proyek menghadapi ketidakpastian mengenai hal yang akan terjadi pada masa depan. Perubahan -perubahan yang dikaji pada analisis sensitivitas adalah (a) Terjadi kenaikan biaya produksi pada usahatani alpukat, (b) Harga jual dari hasil produksi alpukat berubah, dan (c) Volume hasil produksi usahatani alpukat berubah. Analisis kepekaan dilakukan untuk melihat sampai berapa persen perubahan pada biaya, harga jual dan produksi dapat mengakibatkan perubahan pada kriteria investasi, yaitu dari layak menjadi tidak layak untuk dilaksanakan. Menurut Kasmir (2012), rumus untuk menghitung nilai laju kepekaan pada analisis sensitivitas adalah:

$$
\text { Laju Kepekaan }=\frac{\left|\frac{\mathrm{x} 1-\mathrm{x} 0}{\overline{\mathrm{x}}}\right| \times 100 \%}{\left|\frac{\mathrm{y} 1-\mathrm{y} 0}{\overline{\mathrm{y}}}\right| \times 100 \%}
$$

Keterangan:

$\mathrm{x} 1=\mathrm{NPV} / \mathrm{IRR} / \mathrm{PP}$ setelah perubahan

$\mathrm{x} 0=\mathrm{NPV} / \mathrm{IRR} / \mathrm{PP}$ sebelum perubahan

$\overline{\mathrm{x}}=$ Rata-rata perubahan NPV/IRR/PP

y1 = Biaya produksi/harga/suku bunga setelah perubahan

y2 = Biaya produksi/harga/suku bunga sebelum perubahan

$\overline{\mathrm{y}}=$ Rata-rata perubahan biaya produksi/harga/suku bunga

\section{HASIL DAN PEMBAHASAN}

\section{Karakteristik Responden Umur Responden}

Umur responden dapat mempengaruhi produktivitas dalam berusahatani, karena umur sangat mempengaruhi kemampuan fisik seseorang dalam bekerja. Umur produktif berkisar antara 15-64 tahun (Wirosuhardjo, 2004). Umur responden usahatani alpukat dapat dilihat pada tabel 1 berikut:

Anwari, M.Z, Maryati, S., dan Budastra, I.K. 
Tabel 1. Kisaran Umur Petani Alpukat di Kecamatan Sembalun Kabupaten Lombok Timur Tahun 2020

\begin{tabular}{rrrr}
\hline \multirow{2}{*}{ No } & Umur (Tahun) & Jumlah Responden (Jiwa) & Persentase (\%) \\
\hline 1 & $27-35$ & 10 & 25 \\
2 & $36-44$ & 12 & 30 \\
3 & $45-53$ & 11 & 27,5 \\
4 & $54-63$ & 7 & 17,5 \\
\hline
\end{tabular}

Sumber: Data Primer Diolah 2020.

Tabel 1 menunjukkan bahwa umur petani responden dikategorikan umur produktif. Hal ini dilihat dari umur semua petani alpukat dengan persentase terbesar yaitu $(30 \%)$ terdapat pada kisaran umur 36-44 tahun sebanyak 12 orang.

\section{Tingkat Pendidikan}

Tingkat pendidikan responden sangat mempengaruhi tingkat kecepatan tanggap dari petani atas ilmu dan pengalaman yang diperoleh (Soekartawi, 2011). Distribusi responden berdasarkan tingkat pendidikan di Kecamatan Sembalun dapat dilihat pada tabel 2 berikut:

Tabel 2. Tingkat Pendidikan Petani Alpukat di Kecamataan Sembalun Kabupaten Lombok Timur Tahun 2020

\begin{tabular}{rlrr}
\hline \multirow{2}{*}{ No } & Tingkat Pendidikan & Jumlah Responden (Jiwa) & Persentase $(\%)$ \\
\hline 1 & SD & 17 & 42,5 \\
2 & SMP & 10 & 25 \\
3 & SMA & 10 & 25 \\
4 & PT & 3 & 7,5 \\
\hline \multicolumn{2}{c}{ Jumlah } & 40 & 100 \\
\hline
\end{tabular}

Sumber: Data Primer Diolah 2020.

Berdasarkan tabel 2 menunjukkan bahwa pendidikan petani responden tergolong masih rendah. Sebagian besar petani responden adalah tamatan bangku Sekola Dasar yaitu sebanyak 17 orang petani dengan persentase $(42,5 \%)$.

\section{Jumlah Tanggungan Keluarga}

Tanggungan keluarga yang dimaksud dalam penelitian ini adalah jumlah anggota keluarga yang terdiri atas ayah, ibu dan anak yang tinggal dalam satu rumah dan makan dalam satu dapur. Ketersediaan tenaga kerja juga berpengaruh terhadap kegiatan usahatani, karena pada umumnya petani cenderung menggunakan tenaga kerja dalam keluarga untuk menekan biaya produksi, khususnya biaya tenaga kerja. Adapun rincian tanggungan keluarga petani responden dapat dilihat pada tabel 3 berikut:

Tabel 3. Jumlah Anggota Keluarga Petani Alpukat di Kecamataan Sembalun Kabupaten Lombok Timur Tahun 2020

\begin{tabular}{rrrrr}
\hline \multirow{2}{*}{ No } & \multicolumn{2}{c}{$\begin{array}{c}\text { Jumlah Anggota } \\
\text { Keluarga }\end{array}$} & $\begin{array}{c}\text { Jumlah Responden } \\
\text { (Jiwa) }\end{array}$ & Persentase (\%) \\
\hline 1 & & $1-2$ & 13 & 32,5 \\
2 & & $3-4$ & 19 & 47,5
\end{tabular}

Anwari, M.Z, Maryati, S., dan Budastra, I.K. 


\begin{tabular}{rrrrr}
\hline \multicolumn{1}{c}{ No } & Jumlah Anggota & Jumlah Responden & \multicolumn{1}{c}{ Persentase (\%) } \\
\hline 3 & $5-6$ & 7 & 17,5 \\
4 & $7-8$ & 1 & 2,5 \\
\hline & & 40 & 100 \\
\hline
\end{tabular}

Sumber: Data Primer Diolah 2020.

Berdasarkan tabel 3 menunjukan bahwa jumlah tanggungan keluarga terbanyak berkisar diantara 3-4 orang tanggungan yang berjumlah 19 orang dengan persentase $(47,5 \%)$ yang termasuk keluarga besar. Jumlah tanggungan keluarga akan mempengaruhi pola konsumsi dan jumlah pengeluaran biaya sehari-hari rumahtangga petani. Semakin banyak jumlah tanggungan, maka akan semakin besar pula untuk pengeluaran biaya sehari-hari dan besarnya biaya hidup akan berdampak pada ketersediaan modal untuk aktivitas usahatani berikutnya.

\section{Pengalamaan Usahatani}

Dalam melaksanakan kegiatan usahatani, faktor pengalaman merupakan hal yang sangat berperan penting karena pengalaman berusahatani dapat dijadikan sebagai acuan atau dasar yang mampu meminimalkan kegagalan dalam berusahatani sehingga dapat memperoleh produksi dan pendapatan yang optimal. Untuk jelasnya pengalaman berusahatani petani responden dapat dilihat pada tabel 4 berikut:

Tabel 4. Pengalaman Berusahatani Petani Alpukat di Kecamataan Sembalun Kabupaten Lombok Timur Tahun 2020

\begin{tabular}{rrrr}
\hline \multirow{2}{*}{ No } & \multicolumn{1}{c}{ Pengalaman } & $\begin{array}{c}\text { Jumlah Responden } \\
\text { (Jiwa) }\end{array}$ & Persentase (\%) \\
& Berusahatani (Tahun) & 15 & 37,5 \\
2 & $7-12$ & 13 & 32,5 \\
3 & $13-18$ & 8 & 20 \\
4 & $19-24$ & 4 & 10 \\
\hline \multicolumn{7}{r}{} & $25-30$ & 40 & 100 \\
\hline
\end{tabular}

Sumber: Data Primer Diolah 2020.

Berdasarkan tabel 4 menunjukkan bahwa Rata-rata pengalaman usahatani alpukat yaitu 16 tahun sehingga dapat dikatakan sebagian besar responden memiliki pengalaman yang cukup lama dalam berusahatani dan relatif produktif, karena pengalaman mampu mempengaruhi kemampuan berusahatani.

\section{Luas Lahan}

Luas lahan garapan merupakan luas lahan yang diusahakan petani untuk menghasilkan produksi alpukat Adapun rincian luas lahan garapan petani alpukat di Kecamatan Sembalun dapat dilihat pada tabel 5 berikut:

Tabel 5. Luas Lahan Petani Alpukat di Kecamataan Sembalun Kabupaten Lombok Timur Tahun 2020

\begin{tabular}{rrrr}
\hline \multirow{2}{*}{ No } & Luas Lahan (Ha) & Jumlah Responden (Jiwa) & Persentase (\%) \\
\hline 1 & $<0,75$ & 21 & 52,5 \\
2 & $0,75-1,5$ & 14 & 35 \\
3 & $1,6-2,5$ & 4 & 10 \\
4 & $>2,5$ & 1 & 2,5 \\
\hline \multicolumn{7}{r}{ Jumlah } & & 40 & 100 \\
\hline
\end{tabular}

Sumber: Data Primer Diolah 2020.

Anwari, M.Z, Maryati, S., dan Budastra, I.K. 
Berdasarkan tabel 5 menunjukkan bahwa sebagian besar petani responden memiliki luas lahan garapan $<0,75$ ha dengan jumlah 21 orang $(52,5)$. Luas lahan yang dimiliki oleh petani sangat berhubungan dengan biaya produksi yang harus dikeluarkan untuk kegiatan usahatani.

\section{Usahatani Alpukat Di Kecamatan Sembalun}

\section{Sistem Usahatani Monocultur dan Tumpang Sari (Campuran)}

Selain pola tanam monokultur, mayoritas petani alpukat di Kecamatan Sembalun juga mengusahakan alpukat dengan pola tanam tumpangsari. Hal ini dilakukan dengan harapan agar komoditi yang satu dapat menutupi kerugian komoditi yang lain jika terjadi kegagalan panen atau penurunan produksi pada tanaman utama yaitu alpukat.

\section{Umur dan Jumlah Tanaman}

Umur tanaman alpukat dan jumlah tanaman yang dimiliki petani beragam. Umur tanaman mulai dari umur 3 tahun sampai dengan umur 15 tahun, sedangkan jumlah tanaman yang dimiliki petani berkisar antara 120 pohon sampai 800 pohon. Jumlah petani berdasarkan umur tanaman yang dimiliki dapat dilihat pada tabel 6 berikut:

Tabel 6. Jumlah Petani Berdasarkan Umur Tanaman yang Dimiliki

\begin{tabular}{rrr}
\hline Umur Tanaman (Tahun) & Jumlah (Orang) & Persentase (\%) \\
\hline $3-5$ & 8 & 20 \\
$6-8$ & 11 & 27,5 \\
$9-11$ & 8 & 20 \\
$12-15$ & 13 & 32,5 \\
\hline
\end{tabular}

Sumber: Data Primer Diolah 2020.

Berdasarkan tabel 6 diketahui bahwa umur tanaman alpukat terbanyak yaitu 12 sampai 15 tahun sebanyak 13 orang petani dengan persentase sebesar 32,5\% sehingga dari data tersebut dapat diketahui pula bahwa petani alpukat di Kecamatan Sembalun sudah mempunyai pengalaman yang cukup dalam berusahatani alpukat.

\section{Kegiatan Usahatani Masa Investasi Penyiapan Bibit}

Bibit yang digunakan petani responden untuk usahatani alpukat berasal dari pembibitan sendiri dan membeli bibit alpukat. Umur bibit yang siap ditanam adalah 5 6 bulan, dimana bibit tersebut telah memiliki daun berjumlah $4-7$ helai dengan ratarata harga yang didapatkan petani sebesar Rp. 7.000/pohon.

\section{Persiapan Lahan dan Penanaman}

Lahan yang digunakan oleh petani adalah lahan milik sendiri. Petani responden di daerah penelitian menggunakan jarak tanam yang bervariasi untuk tanaman alpukat mulai dari 4 x 5 meter sampai dengan 7 x 5 meter.

\section{Kegiatan Usahatani Masa Operasional Pemupukan}

Pupuk yang sebagian besar dipakai oleh petani responden adalah pupuk kandang, NPK, Urea, TSP, dan KCL.

\section{Pemangkasan (Rambas)}

Rambas merupakan istilah petani setempat untuk kegiatan pemangkasan tanaman alpukat. Petani melakukan pemangkasan pada saat umur tanaman alpukat sudah 
menginjak umur 2 tahun. Pada tanaman menghasilkan, pemangkasan juga bertujuan untuk menghindarkan tanaman dari serangan hama dan penyakit.

\section{Panen}

Buah alpukat dihasilkan saat tanaman berumur 3 tahun. Buah yang matang dicirikan perubahan warna kulit buah menjadi tua, bila buah diketuk menimbulkan suara nyaring, dan bila buah digoyang-goyang akan terdengar goncangan biji.

\section{Input (Biaya) Usahatani}

Biaya usahatani adalah seluruh korbanan yang dipergunakan dalam usahatani untuk menghasilkan penerimaan dan diukur dalam satuan rupiah (Rp). Estimasi biaya dalam suatu investasi digunakan untuk mengetahui besarnya input yang harus disediakan kegiatan usahatani. Estimasi merupakan perencanaan biaya (kas keluar) dan penerimaan (kas masuk) selama kegiatan usahatani. Kurva estimasi biaya per hektar usahatani alpukat berikut:

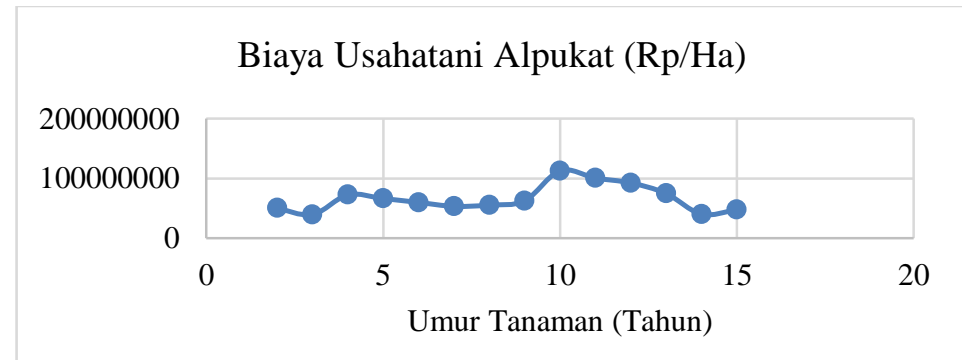

Gambar 1. Biaya Per Hektar Usahatani Alpukat Di Kecamatan Sembalun

Estimasi kurva usahatani alpukat diperoleh dari estimasi biaya usahatani alpukat per hektarnya yang disajikan pada tabel 7 berikut:

Tabel 7. Estimasi Biaya Per Ha Usahatani Alpukat di Kecamataan Sembalun Kabupaten Lombok Timur.

\begin{tabular}{|c|c|}
\hline $\begin{array}{l}\text { Umur Tanaman } \\
\text { (Tahun) }\end{array}$ & $\begin{array}{c}\text { Biaya } \\
(\mathrm{Rp} / \mathrm{Ha})\end{array}$ \\
\hline 2 & 50.589 .773 \\
\hline 3 & 39.553 .209 \\
\hline 4 & 72.551 .934 \\
\hline 5 & 66.341 .149 \\
\hline 6 & 59.848 .385 \\
\hline 7 & 53.310 .646 \\
\hline 8 & 55.362 .863 \\
\hline 9 & 62.571 .372 \\
\hline 10 & 112.907 .669 \\
\hline 11 & 100.621 .510 \\
\hline 12 & 92.511 .496 \\
\hline 13 & 74.748 .773 \\
\hline 14 & 40.195 .290 \\
\hline 15 & 47.597 .073 \\
\hline Jumlah & 928.711 .144 \\
\hline
\end{tabular}

Sumber: Data Primer Diolah 2020.

Anwari, M.Z, Maryati, S., dan Budastra, I.K. 
Berdasarkan tabel 7 biaya tertinggi yaitu saat umur tanaman 10 tahun sedangkan biaya terendah saat umur tanaman 3 tahun. Biaya yang dikeluarkan oleh petani setiap tahunnya fluktuatif, ini tergantung pada kebutuhan tanaman dalam hal ini seperti pupuk atau pestisida setiap tahunnya berbeda-beda.

\section{Biaya Investasi}

Biaya investasi adalah biaya yang dikeluarkan untuk keperluan investasi alpukat sebelum tanaman alpukat menghasilkan yakni tahun pertama dan kedua. Biaya investasi alpukat per hektarnya disajikan pada tabel 8 berikut:

Tabel 8. Biaya Investasi Usahatani Alpukat di Kecamataan Sembalun Kabupaten Lombok Timur Tahun 2020

\begin{tabular}{clr}
\hline \multirow{2}{*}{ Tahun ke- } & \multicolumn{1}{c}{ Jenis Investasi (Per Ha) } & \multicolumn{1}{c}{ Total (Rp) } \\
\cline { 2 - 3 } 1 & Pembelian lahan & 39.624 .646 \\
& Pembelian Bibit & 2.596 .346 \\
& Pembelian Peralatan & 774.646 \\
& Pembelian Pupuk Dasar & 3.474 .263 \\
& Biaya Tenaga Kerja Dalam Keluarga & 471.388 \\
& Biaya Tenaga Kerja Luar Keluarga & 174.221 \\
2 & 47.115 .510 \\
& Pembelian Pupuk & 3.474 .263 \\
\hline \multicolumn{2}{c}{ Total Biaya Investasi } & 50.589 .773 \\
\hline
\end{tabular}

Sumber: Data Primer Diolah 2020.

Berdasarkan tabel 8 diketahui biaya yang dikeluarkan sebelum tanaman menghasilkan yakni tahun pertama sebesar Rp.47.115.510/ha sedangkan pengeluaran tahun kedua hanya untuk perawatan tanaman alpukat yakni membeli pupuk sebesar Rp. 3.474.263/ha sehingga biaya investasi usahatani alpukat dihitung pada akhir tahun kedua dengan jumlah Rp.50.589.773/ha.

Penggunaan alat pertanian didasarkan pada umur ekonomis dan manfaat alat tersebut. Biaya yang dikeluarkan secara tunai pada saat pembelian diasumsikan peralatan tersebut bisa digunakan sampai umur ekonomisnya habis. Rincian biaya peralatan yang digunakan untuk usahatani alpukat dalam luasan lahan 1 ha dapat dilihat pada tabel 9 berikut:

Tabel 9. Biaya Peralatan Per Ha Usahatani Alpukat di Kecamataan Sembalun Kabupaten Lombok Timur Tahun 2020

\begin{tabular}{rlrrrr}
\hline No & \multicolumn{1}{c}{ Peralatan } & $\begin{array}{c}\text { Jumlah } \\
\text { (Unit) }\end{array}$ & $\begin{array}{c}\text { Harga } \\
(\mathrm{Rp} / \text { Unit })\end{array}$ & $\begin{array}{c}\text { Nilai } \\
(\mathrm{Rp})\end{array}$ & $\begin{array}{c}\text { Umur } \\
\text { Ekonomis } \\
\text { (Tahun) }\end{array}$ \\
\hline 1 & Cangkul & 1 & 100.000 & 100.000 & 10 \\
2 & Golok dan Sabit & 3 & 20.000 & 60.000 & 4 \\
3 & Gerobak Dorong & 1 & 500.000 & 500.000 & 5 \\
4 & Mesin Semprot & 1 & 450.000 & 450.000 & 5 \\
5 & Keranjang & 6 & 5.000 & 30.000 & 1 \\
\hline
\end{tabular}

Sumber: Data Primer Diolah 2020.

\section{Biaya Operasional \\ Biaya Tenaga Kerja}

Tenaga kerja yang digunakan dalam usahatani alpukat berasal dari tenaga kerja dalam keluarga dan luar keluarga. Pemakaian tenaga kerja dihitung berdasarkan upah

Anwari, M.Z, Maryati, S., dan Budastra, I.K. 
harian yang dikonversi ke dalam hari orang kerja (HOK) berkisar antara Rp. 30.000/hari sampai Rp. 100.000/hari sesuai kesepakatan.

\section{Biaya Pemupukan dan Pestisida}

Biaya pemupukan merupakan biaya yang sangat diperhatikan oleh petani, penggunaan pupuk yang cukup banyak tiap tahunnya menyebabkan petani harus menyisihkan pendapatan yang cukup besar dalam pembelian pupuk. Biaya pupuk yang dikeluarkan selama usahatani alpukat dapat dilihat pada Tabel 10 berikut:

Tabel 10. Biaya Pupuk Per Ha Usahatani Alpukat di Kecamataan Sembalun

\begin{tabular}{|c|c|c|c|c|c|}
\hline \multirow{2}{*}{$\begin{array}{c}\text { Tahun } \\
\text { Ke- }\end{array}$} & \multicolumn{5}{|c|}{ Pupuk (Rp/Ha) } \\
\hline & Kandang & NPK & Urea & TSP & KCL \\
\hline 1 & 926.346 & 694.887 & 579.072 & 694.887 & 579.072 \\
\hline 2 & 926.346 & 694.887 & 579.072 & 694.887 & 579.072 \\
\hline 3 & 2.693 .333 & 6.060 .000 & 2.525 .000 & 3.030 .000 & 2.525 .000 \\
\hline 4 & 4.800 .000 & 11.520 .000 & 4.800 .000 & 5.760 .000 & 4.800 .000 \\
\hline 5 & 4.800 .000 & 12.000 .000 & 5.000 .000 & 6.000 .000 & 5.000 .000 \\
\hline 6 & 11.733 .333 & 28.800 .000 & 12.000 .000 & 14.400 .000 & 12.000 .000 \\
\hline 7 & 7.668 .148 & 20.128 .889 & 8.387 .037 & 10.064 .444 & 8.387 .037 \\
\hline 8 & 7.141 .500 & 19.044 .000 & 7.935 .000 & 9.522 .000 & 7.935 .000 \\
\hline 9 & 102.000 .000 & 32.400 .000 & 13.500 .000 & 16.200 .000 & 13.500 .000 \\
\hline 10 & 9.291 .333 & 25.340 .000 & 10.558 .333 & 12.670 .000 & 10.558 .333 \\
\hline 11 & 14.234 .483 & 39.144 .828 & 16.310 .345 & 19.572 .414 & 16.310 .345 \\
\hline 12 & 9.295 .484 & 27.127 .742 & 11.303 .226 & 13.563 .871 & 11.303 .226 \\
\hline 13 & 22.400 .000 & 62.400 .000 & 26.000 .000 & 31.200 .000 & 26.000 .000 \\
\hline 14 & 11.705 .882 & 38.541 .176 & 16.058 .824 & 19.270 .588 & 16.058 .824 \\
\hline 15 & 17.180 .488 & 51.541 .463 & 21.475 .610 & 25.770 .732 & 21.475 .610 \\
\hline Jumlah & 136.796 .676 & 375.437 .872 & 157.001 .519 & 188.413 .823 & 157.011 .519 \\
\hline Rata2 & 9.119 .778 & 25.029 .191 & 10.467 .435 & 12.560 .922 & 10.467 .435 \\
\hline
\end{tabular}

Sumber: Data Primer Diolah 2020.

Berdasarkan tabel 10 diketahui bahwa pemberian pupuk kandang, NPK, urea, TSP dan KCL tidak menentu atau berbeda untuk kebutuhan tanaman alpukat sebelum maupun sesudah menghasilkan buah. Pemberian pupuk untuk tanaman berbeda setiap tahunnya, ini dikarenakan pada saat tanaman sudah menghasilkan buah alpukat serta kondisi lingkungan sekitar juga berpengaruh terhadap kebutuhan nutrisi dari tanaman tersebut.

\section{Estimasi Produksi dan Penerimaan Usahatani Alpukat}

Estimasi kurva adalah kurva perhitungan, penilaian atau perkiraan produksi yang akan diperoleh selama melakukan kegiatan usahatani. Estimasi kurva produksi usahatani alpukat diperoleh melalui data jumlah produksi alpukat dalam satuan kilogram/pohon (kg/pohon) dari masing-masing responden petani alpukat yang kemudian dari data tersebut dapat dihitung perkiraan atau estimasi produksi usahatani alpukat di Kecamatan Sembalun dalam satuan kilogram/ha $(\mathrm{kg} / \mathrm{ha})$.

Produksi usahatani yang dimaksud dalam penelitian ini adalah jumlah buah alpukat yang dihasilkan dalam satuan kilogram/Ha $(\mathrm{Kg} / \mathrm{Ha})$. Besar kecilnya produksi alpukat yang didapatkan oleh petani berpengaruh terhadap nilai produksi (penerimaan) yang akan diterima.. Nilai produksi (penerimaan) usahatani merupakan nilai yang diperoleh

Anwari, M.Z, Maryati, S., dan Budastra, I.K. 
dari hasil produksi dikalikan dengan harga yang berlaku. Untuk mengetahui produksi dan penerimaan usahatani alpukat disajikan dalam tabel 11 berikut:

Tabel 11. Penerimaan Per Ha Usahatani Alpukat di Kecamataan Sembalun Kabupaten Lombok Timur

\begin{tabular}{rrrr}
\hline $\begin{array}{c}\text { Umur Tanaman } \\
\text { (Tahun) }\end{array}$ & Produksi (Kg/Ha) & Harga (Rp) & Penerimaan (Rp/Ha) \\
\hline 1 & - & - & - \\
2 & - & - & - \\
3 & 6.793 & 8.000 & 54.344 .828 \\
4 & 12.039 & 8.000 & 96.313 .725 \\
5 & 13.334 & 8.000 & 106.675 .862 \\
6 & 15.368 & 8.000 & 122.947 .368 \\
7 & 17.695 & 8.000 & 141.559 .216 \\
8 & 19.881 & 8.000 & 159.046 .857 \\
9 & 24.628 & 8.000 & 197.021 .384 \\
10 & 25.462 & 8.000 & 203.699 .531 \\
11 & 26.731 & 8.000 & 213.851 .429 \\
12 & 28.567 & 8.000 & 228.533 .333 \\
13 & 31.897 & 8.000 & 255.175 .258 \\
14 & 29.471 & 8.000 & 235.771 .733 \\
15 & 27.844 & 8.000 & 222.751 .220 \\
\hline
\end{tabular}

Sumber: Data Primer Diolah 2020.

Berdasarkan tabel 11 menunjukkan bahwa tahun pertama dan kedua usahatani alpukat belum memberikan hasil karena tanaman alpukat masih belum berproduksi. Pada tahun ketiga, usahatani alpukat mulai memberikan hasil. Produksi tanaman umur 3 tahun sebesar $6.793 \mathrm{~kg} / \mathrm{ha}$ dengan penerimaan sebesar Rp. 54.344.828/ha merupakan yang terendah, hal ini dikarenakan pada umur tersebut tanaman alpukat dikatakan masih dalam proses belajar berbuah. Produksi tanaman alpukat mengalami peningkatan dari umur tanaman 3 tahun sampai umur 13 tahun. Puncak produksi tanaman alpukat yaitu pada umur tanaman 13 tahun dengan jumlah sebesar $31.897 \mathrm{~kg} / \mathrm{ha}$ dengan harga jual rata-rata yang diterima petani adalah $\mathrm{Rp}$. 8.000/kg sehingga diperoleh penerimaan sebesar Rp. 255.175.258/ha. Hal ini sesuai dengan Siregar, dkk. (1999), bahwa tanaman alpukat akan mengalami puncak produksi antara umur tanam ke-10 hingga tahun ke-15. Produksi tanaman alpukat mulai mengalami penurunan produksi mulai dari umur tanaman 13 tahun sampai akhir umur ekonomis tanaman alpukat yaitu tahun ke-15. Hasil dari perhitungan produksi alpukat tersebut dapat diestimasi ke dalam kurva estimasi produksi per hektar usahatani alpukat pada gambar 2 berikut:

Anwari, M.Z, Maryati, S., dan Budastra, I.K. 


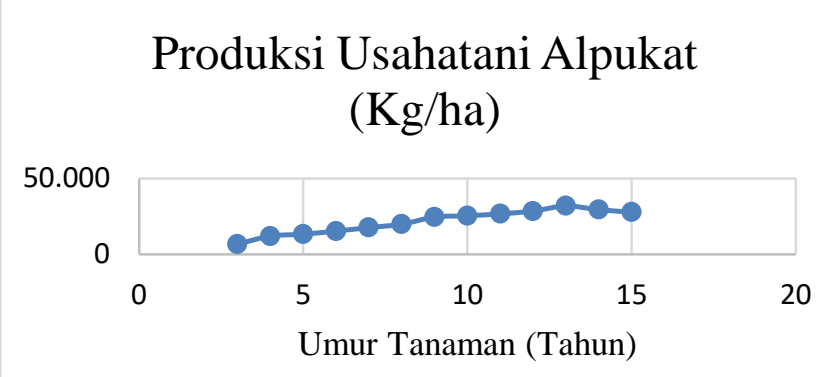

Gambar 2. Produksi Per Hektar Usahatani Alpukat Di Kecamatan Sembalun

\section{Analisis Kelayakan Finansial Investasi Usahatani}

Analisis finansial digunakan untuk mengetahui perbandingan antara jumlah biaya yang dikeluarkan dengan penerimaan dari suatu proses produksi, apakah proses produksi itu layak untuk diusahakan dan dapat memberikan keuntungan. Asumsi yang digunakan adalah tingkat suku bunga kredit perbankan tahun 2019/2020 sebesar 10,5\%. Perhitungan analisis finansial usahatani alpukat di Kecamatan Sembalun dapat dilihat pada Tabel 12 berikut:

Tabel 12. Analisis Finansial Usahatani Alpukat di Kecamatan Sembalun Per Hektar Pada Tingkat Suku Bunga 10,5\% (df = 10,5\%)

\begin{tabular}{|c|c|}
\hline Kriteria & Nilai \\
\hline Net Present value (Rp) & 434.846 .907 \\
\hline Internal Rate of Return (\%) & 54,24 \\
\hline Payback Period (tahun) & 4,3 \\
\hline
\end{tabular}

Sumber: Data Primer Diolah 2020.

\section{Analisis Net Present Value (NPV)}

Tabel 12 menunjukkan besarnya nilai NPV pada tingkat suku bunga kredit perbankan 10,5\% adalah Rp 434.846.907/ha/15 tahun, yang berarti nilai NPV tersebut bernilai positif atau lebih besar dari nol. Hal ini menunjukkan bahwa penerimaan bersih usahatani alpukat lebih besar dari pada total biaya yang dikeluarkan, sehingga dapat dikatakan bahwa usahatani alpukat di Kecamatan Sembalun Kabupaten Lombok Timur menguntungkan dan layak untuk dikembangkan karena nilai NPV > 0. Hasil analisis Net Present Value (NPV) tersebut menunjukkan bahwa selisih antara nilai sekarang dari penerimaan yang diterima dan nilai sekarang biaya yang telah dikeluarkan untuk usahatani alpukat bernilai positif sebesar Rp 434.846.907. Hal ini berarti nilai sekarang penerimaan di masa yang akan datang masih lebih besar dari nilai sekarang biaya yang dikeluarkan di masa yang akan datang.

\section{Analisis Internal Rate of Return (IRR)}

Tabel 12 menunjukkan besarnya nilai IRR pada tingkat suku bunga 10,5\% adalah sebesar 54,24\% untuk usahatani alpukat yang berarti nilai IRR tersebut lebih besar dari tingkat suku bunga yang berlaku. Hal ini menunjukkan bahwa usahatani alpukat di Kecamatan Sembalun Kabupaten Lombok Timur menguntungkan dan layak untuk dikembangkan.

\section{Payback Period (PP)}

Analisis ini digunakan untuk mengetahui jangka waktu pengembalian investasi suatu proyek. Bila waktu pengembalian investasi lebih pendek dari umur proyek, maka proyek tersebut menguntungkan dan layak dijalankan. Berdasarkan tabel 12 didapatkan 
payback period sebesar 4,3. Hal ini berarti investasi awal akan dikembalikan dalam jangka waktu 4,3 tahun, sehingga masa pengembalian modal investasi lebih pendek dari umur ekonomis proyek yaitu 15 tahun.

\section{Analisis Sensitivitas}

Analisis sensitivitas digunakan untuk mengetahui perubahan faktor-faktor dalam dan luar yang mempengaruhi nilai penerimaan dan biaya suatu proyek terhadap kriteria investasi NPV, IRR dan Payback Period. Perubahan faktor yang mempengaruhi penerimaan dan biaya seperti biaya produksi naik sebesar $5,08 \%$ didasarkan pada laju inflasi rata-rata pada tahun 2014 - 2018 (data terlampir) diasumsikan akan menaikan harga input yang digunakan, penurunan produksi alpukat sebesar 7,6\% merupakan persentase penurunan produksi terbesar yang terjadi di lokasi penelitian dan penurunan harga sebesar $25 \%$ karena harga alpukat dipasaran seringkali turun apabila mutu atau kualitasnya menurun.

Laju kepekaan dihitung dari hasil perhitungan analisis sensitivitas yang bertujuan untuk menentukan apakah usahatani alpukat yang dijalankan di Kecamatan Sembalun Kabupaten Lombok Timur peka atau sensitif terhadap perubahan yang terjadi. Apabila laju kepekaan yang diperoleh lebih besar dari satu (> 1), maka proyek peka atau sensitif terhadap perubahan, tetapi apabila laju kepekaan lebih kecil dari satu $(<1)$, maka proyek tidak peka atau tidak sensitif terhadap perubahan. Analisis sensitivitas pada usahatani alpukat di Kecamatan Sembalun Kabupaten Lombok Timur dapat dilihat pada Tabel 13.

Tabel 13. Analisis Sensitivitas Tingkat Suku Bunga 10,5\% Pada Usahatani Alpukat di Kecamatan Sembalun Kabupaten Lombok Timur

\begin{tabular}{rlrrrr}
\hline No & \multicolumn{1}{c}{$\begin{array}{c}\text { Perubahan Yang } \\
\text { Mempengaruhi }\end{array}$} & $\begin{array}{c}\text { Sebelum } \\
\text { Perubahan }\end{array}$ & $\begin{array}{c}\text { Setelah } \\
\text { Perubahan }\end{array}$ & $\begin{array}{c}\text { Laju } \\
\text { Kepekaan }\end{array}$ & Ket \\
\hline 1 & Biaya produksi naik 5,08\% & & & & \\
& NPV (Rp) & 434.846 .907 & 413.635 .384 & 0,07 & TS \\
& IRR (\%) & 54,24 & 50,97 & 0,09 & TS \\
& Payback Period (tahun) & 4,3 & 4,5 & 0,08 & TS \\
2 & Produksi Turun 7,6\% & & & \\
NPV (Rp) & 434.846 .907 & 370.064 .768 & 0,50 & TS \\
& IRR (\%) & 54,24 & 49,05 & 0,31 & TS \\
Payback Period (tahun) & 4,3 & 4,7 & 0,30 & TS \\
3arga Jual Turun 25\% & & & & \\
NPV (Rp) & 434.846 .907 & 221.747 .765 & 0,79 & TS \\
& IRR (\%) & 54,24 & 35,95 & 0,50 & TS \\
Payback Period (tahun) & 4,3 & 6,1 & 0,42 & TS \\
\hline
\end{tabular}

Keterangan: TS=Tidak Sensitif, $\mathrm{S}=$ Sensitif

Sumber: Data Primer Diolah 2020.

Tabel 13 memperlihatkan bahwa pada tingkat suku bunga 10,5\% setelah terjadi peningkatan biaya produksi $5,08 \%$, penurunan jumlah produksi $7,6 \%$ dan penurunan harga jual $25 \%$ nilai NPV masih bernilai positif (NPV >0) dan nilai IRR masih lebih besar dari tingkat suku bunga yang berlaku (IRR > 10,5\%) serta dari sisi payback period masa pengembalian investasi masih lebih pendek dari umur ekonomisnya ( $<15$ tahun), sehingga pada keadaan ini usahatani alpukat di Kecamatan Sembalun Kabupaten Lombok Timur masih layak untuk diusahakan dan dikembangkan.

Laju kepekaan (sensitivitas) usahatani alpukat terhadap peningkatan biaya produksi, penurunan jumlah produksi dan penurunan harga jual bernilai kurang dari satu

Anwari, M.Z, Maryati, S., dan Budastra, I.K. 
$(<1)$ sehingga dapat dikatakan usahatani alpukat di Kecamatan Sembalun Kabupaten Lombok Timur tidak peka atau tidak sensitive terhadap perubahan biaya produksi, jumlah produksi dan harga jual dalam usahatani alpukat.

\section{KESIMPULAN DAN SARAN}

\section{Kesimpulan}

Berdasarkan hasil penelitian dan pembahasan, maka dapat disimpulkan bahwa usahatani alpukat layak diusahakan dan dikembangkan secara finansial karena nilai NPV Rp 434.846.907 (NPV > 0) dan IRR bernilai 54,24\% (IRR > tingkat suku bunga yang berlaku) serta nilai Payback Period 4,3 yang berarti investasi awal akan dikembalikan dalam jangka waktu 4,3 tahun ( $<15$ tahun). Berdasarkan hasil analisis sensitivitas, setelah terjadi kenaikan biaya produksi pada usahatani alpukat sebesar $5,08 \%$, penurunan produksi alpukat sebesar 7,6\% dan penurunan harga jual sebesar $25 \%$ diperoleh nilai $<1$ sehingga usahatani alpukat tetap layak diusahakan dan tidak sensitive terhadap perubahan tersebut.

\section{Saran}

Saran yang dapat diberikan dalam penelitian ini adalah:

1. Bagi petani dan pihak-pihak lain yang berminat untuk berinvetasi pada usahatani alpukat, hasil penelitian ini menunjukkan bahwa usahatani alpukat layak dan menguntungkan untuk diusahakan.

2. Bagi pemerintah daerah, agar mendorong pengembangan usahatani alpukat dengan diintensifkannya penyuluhan tentang penanaman, pemeliharaan, dan penanganan pasca panen. Selain itu diharapkan pemberian bantuan kepada petani yang berminat investasi pada usahatani alpukat karena usahatani tersebut dapat dikembangkan untuk dikelola menjadi agrowisata.

\section{DAFTAR PUSTAKA}

Arikunto Suharsimi, 2006. Prosedur Penelitian. Rineka Cipta. Jakarta.

Badan Pusat Statistik dan Direktorat Jendral Hortikultura. 2018. Luas Panen dan Produksi Alpukat di Indonesia Tahun 2013 - 2017. BPS. Jakarta.

Dinas Pertanian Kabupaten Lombok Timur. 2019. Produksi Buah Alpukat. Dinas Pertanian. Selong.

Kasmir J. 2012. Studi Kelayakan Bisnis. Jakarta: Karya Kencana.

Kusuma, P.T.W.W dan N.K.I. Mayasti. 2014. Analisa kelayakan Finansial Pengembangan Usaha Produksi Komoditas Lokal: Mie Berbasis Jagung. Journal Agritech. 34(2): 194-202.

Ridwan, Akdon. 2007. Rumus dan Data dalam Analisis Statistika. Alfabeta. Bandung.

Soekartawi. 2011. Ilmu Usaha Tani. Universitas Indonesia. Jakarta.

Statistik Produksi Tanaman Hortikultura NTB. 2017. Produksi Buah Alpukat Provinsi NTB. BPS. Mataram.

Sugiyono. 2009. Metode Penelitian Kuantitatif, Kualitatif dan R \& D. Alpabeta. Bandung.

Wirosuhardjo. 2004. Dasar-Dasar Demografi. Fakultas Ekonomi Universitas Indonesia. Jakarta.

Anwari, M.Z, Maryati, S., dan Budastra, I.K. 